\title{
Hubungan Kekuatan Otot Lengan, Kelentukan dan Keseimbangan Dengan Kemampuan Gerakan Senam Meroda
}

\section{The Correlation of Arm Muscle Strength, Flexibility and Balance With Cartwheel Gymnastics Competence}

\author{
Era Sakti Pertiwi ${ }^{1}$, Didik Rilastiyo Budi², Rohman Hidayat ${ }^{3}$, Neva Widanita ${ }^{4}$, Indra Jati \\ Kusuma ${ }^{5}$ \\ 1,2,3,4,5Jurusan Penjas, Fakultas IImu-IImu Kesehatan, Universitas Jenderal Soedirman, Indonesia \\ email: era24sakti@gmail.com¹, didik.rilastiyo.budi@unsoed.ac.id², rohmanhidayati@unsoed.ac.id³3, \\ neffa.widanita@unsoed.ac.id ${ }^{4}$, indrajaks2122@gmail.com ${ }^{5}$ \\ doi) : https://doi.org/10.20884/1.paju.2021.2.2.3797
}

\begin{abstract}
Abstrak
Kemampuan meroda dipengaruhi oleh kekuatan otot lengan, kelentukan dan keseimbangan. Penelitian ini bertujuan untuk mengetahui hubungan kekuatan otot lengan, kelentukan dan keseimbangan dengan kemampuan meroda pada mahasiswa Pendidikan Jasmani Universitas Jenderal Soedirman. Penelitian ini termasuk penelitian korelasional untuk mengetahui hubungan antara variabel bebas dan variabel terikat. Sampel sebanyak 30 orang diambil dengan teknik purposive sampling. Instrumen penelitian kekuatan otot lengan menggunakan push up, fleksibilitas menggunakan side split, dan keseimbangan menggunakan tes bass yang dimodifikasi. Uji statistik menggunakan normalitas, linieritas, product moment pearson, dan korelasi ganda. Hasil: (1) Ada hubungan yang signifikan antara kekuatan otot lengan dengan kemampuan meroda dengan nilai $r=0,638$ dan sumbangan efektif sebesar $20,7 \%$. (2) Terdapat hubungan yang signifikan antara fleksibilitas dengan kemampuan meroda dengan nilai $r=-0,709$ dan sumbangan efektif $27,8 \%$. (3) Terdapat hubungan yang signifikan antara keseimbangan dengan kemampuan meroda dengan nilai $r=0,535$ dengan sumbangan efektif sebesar $14,7 \%$. (4) Ada hubungan yang signifikan antara kekuatan otot lengan, kelentukan dan keseimbangan dengan kemampuan meroda dengan nilai $R$ square $=0,632$. Kesimpulan dari penelitian ini yaitu terdapat hubungan yang signifikan antara kekuatan otot lengan, kelentukan dan keseimbangan dengan kemampuan meroda pada mahasiswa Pendidikan Jasmani Universitas Jenderal Soedirman. Penelitian selanjutnya dapat mengungkap hubungan antara kondisi psikologis atau keterampilan motorik dengan keberhasilan dalam melakukan gerakan senam meroda.
\end{abstract}

Kata Kunci : Kekuatan Otot Lengan, Fleksibilitas, Keseimbangan, Meroda

\footnotetext{
Abstract

The ability of cartwheel is influenced by arm muscle strength, flexibility and balance. The research aims to find out the correlation of arm muscle strength, flexibility and balance with the cartwheel ability on physical education student at Jenderal Soedirman University. This study includes correlational research to find

Alamat Koresponden : Jurusan Penjas, Fakultas IImu-IImu Kesehatan, Universitas Jenderal Soedirman, Indonesia

Email : era24sakti@gmail.com

(c) (7)

Jurnal Physical Activity Journal (PAJU) This work is licensed under a Creative Commons Attribution $\underline{4.0 \text { International License. }}$
} 
out the correlation between independent variables and dependent variables. $A$ sample of 30 students was taken with purposive sampling techniques. Arm muscle strength research instruments use push ups, flexibility using side splits, and balance using modified bass tests. Statistical tests use normality, linearity, pearson product moment, and multiple correlation. Results: (1) There is a significant correlation between arm muscle strength with cartwheel ability with a value of $r=0.638$ and an effective contribution of $20.7 \%$. (2) There is a significant correlation between flexibility with cartwheel ability with a value of $r=-0.709$ and an effective contribution of $27.8 \%$. (3) There is a significant correlation between balance with cartwheel ability with a value of $r=0.535$ and an effective contribution of $14.7 \%$. (4) There is a significant correlation between arm muscle strength, flexibility and balance with cartwheel ability with a value of $R$ square= 0.632 . The conclusion of this study is that there is a significant relationship between arm muscle strength, flexibility and balance with the ability to wheel on Physical Education students at Jenderal Soedirman University. Further research can reveal the relationship between psychological conditions or motor skills and the success of doing wheelchair exercises.

Keywords : Arm Muscle Strength, Flexibility, Balance, Cartwheel

\section{PENDAHULUAN}

Pendidikan jasmani merupakan sebuah proses dalam pendidikan yang mempunyai tujuan meningkatkan kebugaran fisik guna mencapai tujuan yang diinginkan. Pendidikan jasmani merupakan satu-satunya jenis pendidikan formal di sekolah yang dominan menggunakan aktivitas jasmani sebagai proses pembelajaran (Abduljabar, 2011; Setiawan et al., 2020).

Budi et al. (2019) menjelaskan bahwa pendidikan jasmani mempunyai tujuan meningkatkan kesegaran fisik serta meningkatkan keterampilan peserta didik dalam bidang olahraga. Adapun tujuan lainnya yaitu bersifat menyeluruh dari pendidikan jasmani yaitu menumbuhkan kecerdasan secara kognitif, afektif dan psikomotor. Penerapan dasar materi pendidikan jasmani yaitu terdiri dari olahraga permainan, atletik, akuatik, dan senam (Suherman, 2009).

Senam merupakan suatu aktivitas guna mengembangkan komponen fisik dan motorik yang dilakukan secara sistematis (Budi, 2021; Sari \& Sugiarto, 2016). Ristanti, et.al. (2019) dan Widowati \& Rasyono (2013) juga menjelaskan senam merupakan aktivitas fisik yang mampu memaksimalkan tumbuh kembang seorang anak melalui aktivitas gerak yang dapat membangun komponen kondisi fisik seperti kekuatan, kelentukan hingga daya tahan untuk menambah kesegaran jasmani. Senam diimplemetasikan dalam mata kuliah di Program Studi Penjas Unsoed Purwokerto salah 
Era Sakti Pertiwi, Didik Rilastiyo Budi, Rohman Hidayat, Neva Widanita \& Indra Jati Kusuma | Hubungan Kekuatan Otot Lengan, Kelentukan dan Keseimbangan Dengan Kemampuan Gerak Senam Meroda

satunya yaitu dalam mata kuliah senam. Mata kuliah senam bagi mahasiswa dilakukan dalam beberapa tahap yaitu senam dasar (senam lantai), senam alat dan pembelajaran senam.

Mata kuliah senam dasar terdiri dari beberapa kompetensi gerakan seperti gerakan guling depan, guling belakang, meroda, dan gerakan rangkaian lainnya. Mata kuliah senam alat terdiri dari alat palang sejajar untuk mahasiswa putra dan balance beam untuk putri. Mata kuliah pembelajaran senam terdiri dari materi teknik pembelajaran senam dengan tutor sebaya (Parta, 2016; Mulyana, 2017). Salah satu permasalahan yang dialami adalah mahasiswa harus bisa menguasai berbagai gerakan dengan terbatasnya sarana dan prasarana, waktu dan materi yang diberikan.

Salah satu gerakan senam lantai yang perlu dikuasai oleh mahasiswa yaitu teknik gerakan meroda. Gerak meroda yaitu gerakan yang dilakukan kesamping dengan kedua tangan sebagai tumpuan saat posisi kaki terbuka lebar atau kangkang di atas tumpuan dengan posisi badan terbalik (Oksyalia et al., 2018). Peneliti ingin melakukan penelitian tentang gerak meroda karena gerak meroda merupakan gerak yang unik. Gerakan meroda pada senam lantai merupakan gerak yang komplek dan berbeda dengan gerak dasar yang lain (Murtaqi et al., 2018). Banyak yang menganggap gerak meroda merupakan gerakan yang mudah dilakukan, akan tetapi dalam kenyataannya masih banyak yang mengalami kesulitan dalam melakukan gerak tersebut, sehingga peneliti tertarik untuk meneliti tentang gerak meroda.

Beberapa faktor yang mempengaruhi keberhasilan melakukan gerakan meroda salah satunya yaitu faktor kondisi fisik (Oksyalia et al., 2018; Wuryantoro \& Muktiani, 2011). Faktor kondisi fisik yang baik akan medukung kemampuan gerak untuk mencapai prestasi yang tinggi. Komponen kondisi fisik yang dimaksud yaitu kekuatan, kelentukan, keseimbangan dan power. Disamping itu, peneliti ingin menekankan otot yang dominan digunakan dalam kemampuan gerak meroda yang berdasarkan pada pengalaman peneliti sebagai atlet senam.

Kekuatan otot lengan diperlukan untuk menahan lengan supaya tetap lurus saat bertumpu, menopang berat tubuh dan menjaga keseimbangan tubuh saat menjadi tumpuan pada posisi badan saat terbalik serta mendorong agar bisa kembali pada posisi berdiri tegak (Arwih, 2019; Rindawan \& Mulyajaya, 2016). Akan tetapi, dalam praktiknya masih banyak mahasiswa yang lengannya menekuk pada saat bertumpu dalam keadaan 
posisi badan terbalik. Selain itu, kurang kuatnya dorongan tangan yang menyebabkan kurang sempurnanya pada saat penyelesaian gerakan. Hal itu bisa berarti bahwa kekuatan otot lengan yang dimiliki mahasiswa masih kurang.

Kelentukan diperlukan pada saat kaki yang berada didepan, di ayunkan dan mengangkat kaki tersebut keatas sampai posisi kedua kaki kangkang diatas. Akan tetapi, dalam praktiknya kaki mahasiswa masih banyak yang menekuk saat posisi badan terbalik dan posisi kaki seharusnya kangkang dan lurus pada saat posisi di atas kepala. Hal ini juga berarti bahwa kelentukan pada kaki yang dimiliki oleh mahasiswa bisa dikatakan kurang maksimal dalam kelentukkannya.

Keseimbangan diperlukan pada saat awal maupun akhir gerakan meroda yaitu dimulai dari awalan melangkahkan salah satu kaki ke depan, lalu saat akhir gerakan meletakkan kaki kanan/kiri hingga posisi badan kembali berdiri tegak (Milham, 2014). Akan tetapi, pada praktiknya, masih banyak mahasiswa yang goyang atau tidak seimbang untuk berdiri, itu juga berarti bahwa keseimbangan yang dimiliki mahasiswa masih kurang.

Berdasarkan hasil observasi awal penelitian dan hasil penilaian gerak meroda serta diskusi dengan dosen pengampu mata kuliah senam di Jurusan Penjas Unsoed Purwokerto, disimpulkan bahwa terdapat mahasiswa yang mengalami kesulitan melakukan gerak meroda terutama untuk mahasiswa laki- laki. Hal ini terjadi dimungkinkan jumlah mahasiswa laki-laki lebih dominan daripada mahasiswa perempuan serta dimungkinkan dari faktor fisik yang kurang maksimal.

Dilihat dari uraian latar belakang permasalahan diatas, peneliti tertarik meneliti tiga komponen fisik yaitu kekuatan otot lengan, kelentukan dan keseimbangan serta mencari tahu apakah ketiga komponen fisik tersebut ada hubungan yang signifikan dengan kemampuan gerak meroda.

\section{METODE}

Penelitian ini merupakan jenis penelitian korelasional. Tujuan dari penelitian korelasional adalah untuk mengetahui ada atau tidaknya hubungan antara variabelvariabel yang akan diteliti (Sugiyono, 2016). Selain itu, penelitian ini juga akan mengungap seberapa besar hubungan dari masing-masing variabel, sehingga dapat diketahui faktor yang lebih dominan dari setiap variabel. Dibawah ini merupakan desain penelitian yang digunakan oleh peneliti. 
Era Sakti Pertiwi, Didik Rilastiyo Budi, Rohman Hidayat, Neva Widanita \& Indra Jati Kusuma | Hubungan Kekuatan Otot Lengan, Kelentukan dan Keseimbangan Dengan Kemampuan Gerak Senam Meroda

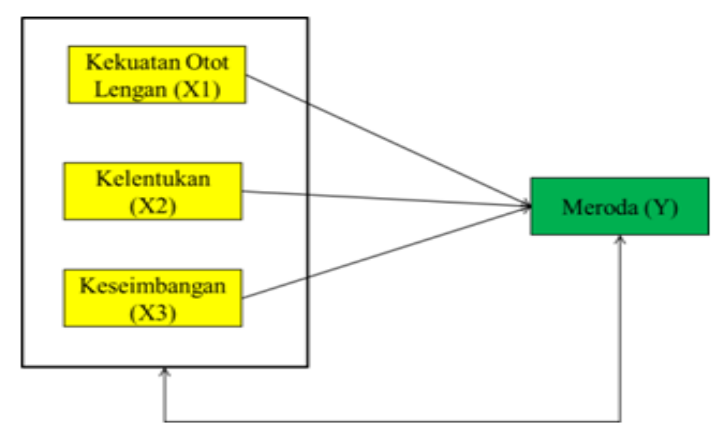

Gambar 1. Desain Penelitian

Populasi yang digunakan pada penelitian ini adalah mahasiswa laki-laki Penjas Unsoed Purwokerto berjumlah 146 mahasiswa, pengambilan sampel menggunakan teknik purposive sampling berdasarkan kriteria inklusi dan kriteria eksklusi.

1. Kriteria Inklusi:
a) Mahasiswa PJKR Unsoed 2019.
b) Berjenis kelamin laki-laki.
c) Bersedia diteliti dan telah mengisi kuesioner.

2. Kriteria Eksklusi:

a) Sakit dan dalam keadaan cedera.

b) Tidak bisa hadir pada saat penelitian karena suatu halangan.

Berdasarkan kriteria inklusi dan eksklusi diperoleh sampel penelitian sejumlah 30 mahasiswa. Alat ukur yang digunakan yaitu tes push up untuk mengukur kekuatan otot lengan, tes side splits untuk mengukur kelentukan, tes modifikasi bass test untuk mengukur keseimbangan dinamis dan tes gerak meroda (Komarudin, 2016). Pengumpulan data diperoleh dengan cara mahasiswa melakukan tes meroda dengan dinilai oleh dua orang ahli senam (expert judgemen) yang terdiri dari saru dosen senam dan satu wasit senam tingkat provinsi. Kriteria penilaian seperti tertera pada tabel 1. dibawah ini (Fenanlampir \& Faruq, 2015)

Tabel 1. Kriteria Penilaian

\begin{tabular}{llccc}
\hline No & Klasifikasi & $\begin{array}{c}\text { Kekuatan } \\
(\text { Push } \text { Up })\end{array}$ & $\begin{array}{c}\text { Kelentukan } \\
\text { (Side Split) }\end{array}$ & $\begin{array}{c}\text { Keseimbangan } \\
\text { (Bass Test) }\end{array}$ \\
\hline 1 & Baik Sekali & $>70$ & $3,24 \mathrm{~cm}-0 \mathrm{~cm}$ & \\
\hline 2 & Baik & $54-69$ & $8 \mathrm{~cm}-3,25 \mathrm{~cm}$ & $75-100$ \\
\hline 3 & Cukup & $38-53$ & $17,50 \mathrm{~cm}-8,01 \mathrm{~cm}$ & $48-74$ \\
\hline
\end{tabular}




\begin{tabular}{llccc}
\hline 4 & Kurang & $22-37$ & $22,50 \mathrm{~cm}-17,51 \mathrm{~cm}$ & $0-47$ \\
\hline 5 & Kurang sekali & $<21$ & $22,51 \mathrm{~cm}-$ ke atas & \\
\hline
\end{tabular}

Pengolahan data statistik menggunakan bantuan aplikasi SPSS 25, dengan melalui uji prasyarat yaitu uji normalitas menggunakan shapiro wilk dan uji linearitas menggunakan test for linearity, selanjutnya uji hipotesis sederhana dengan uji pearson product moment dan korelasi berganda menggunakan uji regresi linier.

\section{HASIL}

Data penelitian ini terdiri dari tiga variabel bebas, yaitu: kekuatan otot lengan, kelentukan dan keseimbangan dan satu variabel terikat yaitu kemampuan gerak meroda. Data tersebut kemudian di olah secara statistik dengan bantuan aplikasi SPSS 25. Data hasil persebaran distribusi frekuensi sesuai norma kekuatan otot lengan dari mahasiswa Penjas Unsoed sebanyak 30 mahasiswa dapat dilihat pada tabel 2. dibawah ini.

Tabel 2. Distribusi Frekuensi Kekuatan Otot Lengan

\begin{tabular}{llccc}
\hline No & Klasifikasi & Kelas Interval & Frekuensi & Frekuensi Relatif(\%) \\
\hline 1 & Baik Sekali & $>70$ & 0 & 0 \\
\hline 2 & Baik & $54-69$ & 0 & 0 \\
\hline 3 & Cukup & $38-53$ & 17 & 56,67 \\
\hline 4 & Kurang & $22-37$ & 13 & 43,33 \\
\hline 5 & Kurang sekali & $<21$ & 0 & 0 \\
\hline
\end{tabular}

Berdasarkan analisis data perhitungan variabel kekuatan otot lengan menggunakan PAN diketahui sebanyak 17 mahasiswa atau 56,67\% mahasiswa dengan klasifikasi cukup dan sebanyak 13 mahasiswa atau 43,33\% mahasiswa dengan klasifikasi kurang.

Data hasil persebaran distribusi frekuensi sesuai norma kelentukan dari mahasiswa Penjas Unsoed sebanyak 30 mahasiswa, terlihat pada tabel 3. dibawah ini.

Tabel 3. Distribusi Frekuensi Kelentukan

\begin{tabular}{ccccc}
\hline No & Klasifikasi & Kelas Interval & Frekuensi & Frekuensi Relatif (\%) \\
\hline 1 & Baik Sekali & $3,24 \mathrm{~cm}-0 \mathrm{~cm}$ & 0 & 0 \\
\hline
\end{tabular}


Era Sakti Pertiwi, Didik Rilastiyo Budi, Rohman Hidayat, Neva Widanita \& Indra Jati Kusuma | Hubungan Kekuatan Otot Lengan, Kelentukan dan Keseimbangan Dengan Kemampuan Gerak Senam Meroda

\begin{tabular}{llccc}
\hline 2 & Baik & $8 \mathrm{~cm}-3,25 \mathrm{~cm}$ & 4 & 13,33 \\
\hline 3 & Sedang & $17,50 \mathrm{~cm}-8,01 \mathrm{~cm}$ & 13 & 43,33 \\
\hline 4 & Kurang & $22,50 \mathrm{~cm}-17,51 \mathrm{~cm}$ & 8 & 26,67 \\
\hline 5 & Kurang sekali & $22,51 \mathrm{~cm}-$ ke atas & 5 & 16,67 \\
\hline
\end{tabular}

Berdasarkan analisis data perhitungan variabel kelentukan menggunakan Penilaian Acuan Norma (PAN) diketahui sebanyak 4 mahasiswa atau 13,33\% mahasiswa dengan klasifikasi baik, sebanyak 13 mahasiswa atau 43,33\% mahasiswa dengan klasifikasi sedang, sebanyak 8 mahasiswa atau 26,67\% mahasiswa dengan klasifikasi kurang dan sebanyak 5 mahasiswa atau 16,67\% mahasiswa dengan klasifikasi sangat kurang.

Data hasil persebaran distribusi frekuensi sesuai norma keseimbangan dari mahasiswa Penjas Unsoed sebanyak 30 mahasiswa, dapat dilihat pada tabel 4. dibawah ini.

Tabel 4. Distribusi Frekuensi Keseimbangan

\begin{tabular}{llccc}
\hline No & Klasifikasi & Kelas Interval & Frekuensi & Frekuensi (\%) \\
\hline 1 & Baik & $75-100$ & 30 & 100 \\
\hline 2 & Sedang & $48-74$ & 0 & 0 \\
\hline 3 & Kurang & $0-47$ & 0 & 0
\end{tabular}

Berdasarkan analisis data perhitungan variabel keseimbangan menggunakan Penilaian Acuan Norma (PAN) diketahui sebanyak 30 mahasiswa atau 100\% mahasiswa dengan klasifikasi baik.

Data hasil persebaran distribusi frekuensi sesuai norma kemampuan gerak meroda dari mahasiswa Penjas Unsoed sebanyak 30 mahasiswa dapat dilihat pada tabel 5. dibawah ini.

Tabel 5. Distribusi Frekuensi Kemampuan Gerak Meroda

\begin{tabular}{llccc}
\hline No & Klasifikasi & Kelas Interval & Frekuensi & Frekuensi (\%) \\
\hline 1 & Baik Sekali & $91-100$ & 2 & 6,67 \\
\hline 2 & Baik & $71-90$ & 27 & 90 \\
\hline 3 & Sedang & $61-70$ & 1 & 3,33 \\
\hline
\end{tabular}




\begin{tabular}{lllll}
\hline 4 & Kurang & $<60$ & 0 & 0
\end{tabular}

Berdasarkan analisis data perhitungan variabel kemampuan gerak meroda menggunakan Penilaian Acuan Norma (PAN) diketahui sebanyak 2 mahasiswa atau 6,67\% mahasiswa dengan klasifikasi baik sekali, sebanyak 27 mahasiswa atau 43,33\% mahasiswa dengan klasifikasi baik, dan sebanyak 1 mahasiswa atau 3,33\% mahasiswa dengan klasifikasi sedang.

\section{Hasil Uji Prasyarat}

\section{Uji Normalitas Data}

Uji Normalitas dilakukan untuk mengidentifikasi kondisi sebaran data penelitian terdistribusi normal atau tidak. Peneliti menggunakan program aplikasi SPSS 25 untuk mengetahui hasil dari olah data. Uji normalitas ini menggunakan uji Shapiro Wilk. Data dikatan terdistribusi normal apabila nilai signifikansi atau nilai $p$ lebih besar dari 0,05 (sig $>0,05)$. Hasil uji normalitas data penelitian dapat dilihat pada tabel 6 . di bawah ini.

Tabel 6. Uji Normalitas

\begin{tabular}{llll}
\hline \multirow{2}{*}{ Variabel } & \multicolumn{3}{c}{ Shapiro-Wilk } \\
\cline { 2 - 4 } & Statistic & Df & Sig. \\
\hline Kekuatan Otot Lengan &, 949 & 30 &, 160 \\
\hline Kelentukan &, 947 & 30 &, 142 \\
\hline Keseimbangan &, 963 & 30 &, 359 \\
\hline Kemampuan Gerak Meroda &, 938 & 30 &, 082 \\
\hline
\end{tabular}

Berdasarkan tabel diatas, hasil dari Test of Normality diperoleh nilai signifikansi kekuatan otot lengan sebesar 0,160 , kelentukan sebesar 0,142 , keseimbangan sebesar 0,359 dan kemampuan gerak meroda sebesar 0,082 . Hasil menunjukkan data penelitian berdistribusi secara normal.

\section{Uji Linearitas Data}

Uji linearitas dilakukan untuk mengidentifikasi bentuk hubungan apakah liniear atau tidak antara variabel bebas dengan variabel terikat. Ketentuan liniearitas yaitu apabila nilai signifikansi lebih besar dari 0,05 (sig>0,05). Hasil uji linieritas data penelitian dapat dilihat pada tabel 7. dibawah ini. 
Era Sakti Pertiwi, Didik Rilastiyo Budi, Rohman Hidayat, Neva Widanita \& Indra Jati Kusuma | Hubungan Kekuatan Otot Lengan, Kelentukan dan Keseimbangan Dengan Kemampuan Gerak Senam Meroda

Tabel 7. Uji Linearitas Data

\begin{tabular}{llc}
\hline Variabel & Linearitas & sig \\
\hline Kekuatan Otot Lengan*Kemampuan Gerak Meroda & Deviation from Linearity & .625 \\
\hline Kelentukan* Kemampuan Gerak Meroda & Deviation from Linearity & .415 \\
\hline Keseimbangan*Kemampuan Gerak Meroda & Deviation from Linearity & .841 \\
\hline
\end{tabular}

Berdasarkan tabel diatas, hasil dari nilai signifikansi dalam Deviation from Linearity kekuatan otot lengan dengan kemampuan gerak meroda sebesar 0,625, kelentukan dengan kemampuan gerak meroda sebesar 0,415 dan keseimbangan dengan kemampuan gerak meroda sebesar 0,841. Hasil menunjukan ketiga variabel bebas ada hubungan linear secara signifikan dengan variabel terikat.

\section{Uji Hipotesis}

Analisis yang digunakan dalam penelitian ini adalah uji korelasi ganda dengan uji korelasi ganda menggunakan uji Regresi Liniear. Uji ini dilakukan untuk mengetahui adanya hubungan antara variabel kekuatan otot lengan, kelentukan dan keseimbangan dengan variabel kemampuan gerak meroda. Uji korelasi ini menggunakan bantuan software SPSS 25. Jika nilai signifikansi $<0,05$ maka dapat dikatakan bahwa variabel mempunyai hubungan yang signifikan. Hasil uji korelasi antara variabel penelitian dapat dilihat pada tabel 8. dibawah ini

Tabel 8. Uji Korelasi Ganda

\begin{tabular}{|c|c|c|c|c|c|c|c|c|c|c|c|}
\hline \multicolumn{12}{|c|}{ Model Summary } \\
\hline \multirow{3}{*}{ Model } & \multirow{3}{*}{$\mathrm{R}$} & \multirow{3}{*}{$\begin{array}{l}\mathrm{R} \\
\text { Square }\end{array}$} & \multirow{3}{*}{$\begin{array}{l}\text { Adjusted R } \\
\text { Square }\end{array}$} & \multirow{2}{*}{\multicolumn{2}{|c|}{$\begin{array}{l}\text { Std. Error } \\
\text { of the }\end{array}$}} & \multicolumn{6}{|c|}{ Change Statistics } \\
\hline & & & & & & $\mathrm{R}$ Square & $\mathrm{F}$ & df1 & df2 & Sig. & $\mathrm{F}$ \\
\hline & & & & Estim & & Change & Change & & & Change & \\
\hline 1 & ,795a & 632 & 589, & 4,259 & & ,632 & 14,870 & 3 & 26 & 000 & \\
\hline
\end{tabular}

Berdasarkan hasil analisis data diatas, variabel kekuatan otot lengan, kelentukan dan keseimbangan dengan variabel kemampuan gerak meroda diperoleh nilai signifikansi sebesar= $0,000(p<0,05)$, yang berarti bahwa antara variabel mempunyai hubungan yang signifikan. Nilai koefisien korelasi $R=0,795$, yang berarti bahwa korelasi antara variabel kekuatan otot lengan, kelentukan dan keseimbangan dengan variabel kemampuan gerak meroda memiliki korelasi yang sangat kuat. 


\section{PEMBAHASAN}

Hasil analisis antara variabel kekuatan otot lengan dengan variabel kemampuan gerak meroda menunjukkan bahwa ada hubungan yang signifikan antara kekuatan otot lengan dengan kemampuan gerak meroda pada mahasiswa Penjas Unsoed. Kekuatan otot lengan memiliki sumbangan efektif (SE) sebesar 20,7\% yang artinya kekuatan otot lengan memiliki sumbangan efektif yang berada di tengah-tengah diantara ketiga variabel bebas.

Hasil penelitian ini dapat disimpulkan bahwa semakin besar kekuatan otot lengan yang dimiliki maka kemampuan gerak meroda semakin baik saat menjadi tumpuan dan sebaliknya semakin kecil kekuatan otot lengan yang dimiliki maka kemampuan gerak meroda menjadi kurang baik. Hasil penelitian terdahulu menunjukan bahwa kekuatan dan power otot lengan memiliki korelasi yang kuat dalam keberhasilan gerakan senam handspring (Yulianto, 2018). Semakin banyak nilai kekuatan otot lengan yang diperoleh maka kekuatan otot lengan semakin baik dan semakin tinggi perolehan nilai kemampuan gerak meroda maka semakin baik dalam melakukan gerak meroda.

Selanjutnya, hasil analisis antara variabel kelentukan dengan kemampuan gerak meroda menunjukkan bahwa, ada hubungan yang signifikan antara kelentukan dengan kemampuan gerak meroda pada mahasiswa Penjas Unsoed. Kelentukan memiliki sumbangan efektif sebesar $27,8 \%$, yang artinya kelentukan memiliki sumbangan paling dominan diantara ketiga variabel bebas.

Hasil penelitian ini dapat disimpulkan bahwa kelentukan berhubungan negatif dengan kemampuan gerak meroda, yang artinya semakin rendah nilai kelentukan maka semakin tinggi nilai kemampuan gerak meroda dan sebaliknya semakin tinggi nilai kelentukan maka semakin kurang baik kemampuan gerak meroda. Semakin rendah nilai kelentukan maka semakin baik dalam kelentukannya dan semakin tinggi nilai kemampuan gerak meroda maka semakin baik kemampuan gerak meroda.

Hasil analisis pengujian korelasi pearson product moment keseimbangan dengan kemampuan gerak meroda menunjukkan bahwa ada hubungan yang signifikan antara keseimbangan dengan kemampuan gerak meroda pada mahasiswa Penjas Unsoed. Keseimbangan memiliki sumbangan efektif sebesar $14,7 \%$, yang artinya keseimbangan memiliki sumbangan efektif yang kurang dominan atau rendah dari ketiga variabel bebas. 
Era Sakti Pertiwi, Didik Rilastiyo Budi, Rohman Hidayat, Neva Widanita \& Indra Jati Kusuma | Hubungan Kekuatan Otot Lengan, Kelentukan dan Keseimbangan Dengan Kemampuan Gerak Senam Meroda

Hasil penelitian ini dapat disimpulkan bahwa keseimbangan memiliki sumbangan yang paling kurang dominan atau paling rendah dan memiliki faktor keberhasilan yang paling rendah diantara ketiga variabel, akan tetapi semakin baik keseimbangan maka akan menunjang dalam melakukan Gerakan meroda. Hasil penelitian terdahulu menunjukann bahwa keseimbangan berhubungan positif dengan keberhasilan Gerakan meroda (Maulana et al., 2015).

Selanjutnya, hasil analisis menggunakan uji korelasi ganda menunjukkan bahwa ada hubungan yang signifikan kekuatan otot lengan, kelentukan dan keseimbangan dengan kemampuan gerak meroda pada mahasiswa Penjas Unsoed. Kekuatan otot lengan, kelentukan dan keseimbangan memiliki nilai koefisien korelasi (r) sebesar= 0,795 yang artinya memiliki hubungan yang positif dengan korelasi yang kuat.

Kekuatan otot lengan, kelentukan dan keseimbangan yang diteliti merupakan faktor keberhasilan yang dilihat dari kondisi fisik. Masing-masing variabel bebas memiliki hubungan terhadap keberhasilan kemampuan gerak meroda. Hasil dari sumbangan efektif dan faktor keberhasilan koefisien korelasi ( $r$ ) dari masing-masing variabel bebas yang paling besar yaitu kelentukan, kekuatan otot lengan dan keseimbangan.

Hasil analisis nilai $\mathrm{R}$ square yang dimiliki kekuatan otot lengan, kelentukan dan keseimbangan dengan kemampuan gerak meroda pada mahasiswa Penjas Unsoed yaitu sebesar $63,2 \%$. Hal ini membuktikan bahwa variabel kekuatan otot lengan, kelentukan dan keseimbangan memberikan peranan yang besar terhadap keberhasilan gerak meroda. Hasil penelitian terdahulu menunjukan bahwa keterampilan Gerakan Roundoff dipengaruhi oleh berbagai faktor fisik dominan seperti kekuatan dan power otot tangan serta keseimbangan (Lubis \& Heri, 2018). Sementara kekurangan 36,8\% dikarenakan masih banyak variabel bebas lain diluar dari ketiga variabel penelitian ini yang juga berhubungan dengan kemampuan gerak meroda atau memberikan sumbangan terhadap keberhasilan gerak meroda. Variabel lain yang dimaksud dimungkinkan yaitu variabel dari faktor postur tubuh atau struktur tubuh, faktor fisik lainnya, faktor teknik dan faktor mental atau psikologis.

\section{SIMPULAN}

Berdasakan hasil dan pembahasan dapat disimpulkan bahwa terdapat hubungan yang signifikan antara kekuatan otot lengan, kelentukan otot dan keseimbangan dengan 
kemampuan gerakan senam lantai meroda. Hubungan paling kuat yaitu kelentukan otot, kemudian kekuatan otot lengan dan yang terakhir adalah faktor keseimbangan. Berdasarkan hasil data, maka perlu ditingkatkan ketiga faktor tersebut sehingga mahasiswa dapat melakukan gerakan senam meroda dengan baik. Saran untuk penelitian selanjutnya yaitu dapat mengkaji meengenai faktor fisik, teknik dan bahkan faktor psikologis yang dapat mendukung dalam melakukan teknik gerakan senam meroda.

\section{REFERENSI}

Abduljabar, B. (2011). Pengertian pendidikan jasmani. IImu Pendidikan.

Arwih, M. Z. (2019). Hubungan Kekuatan Otot Lengan Dengan Kemampuan Handstand Pada Olahraga Senam Lantai Mahasiswa Penjaskesrek Angkatan 2016 Kelas B Fkip Uho. Jurnal IImu Keolahragaan. https://doi.org/10.24114/jik.v17i2.12302

Budi, D. R. (2021). Evaluasi Pembelajaran Senam di Masa Pandemi Covid 19 Berbasis eLearning Eldiru. 1-7. https://doi.org/10.31219/osf.io/qtb46

Budi, D. R., Hidayat, R., \& Febriani, A. R. (2019). The Application of Tactical Approaches in Learning Handballs. JUARA: Jurnal Olahraga. https://doi.org/10.33222/juara.v4i2.534

Dewi Irma Ristanti, Wawan Setiawan, \& Donny Setiawan. (2019). Pengaruh Pembelajaran Menggunakan Media Hullahop Terhadap Peningkatan Hasil Belajar Senam Lantai Pada Siswa Kelas VIII Di SMP Negeri 1 Pakusari. Jurnal Kejaora (Kesehatan Jasmani Dan Olahraga). https://doi.org/10.36526/kejaora.v4i1.617

Fenanlampir, A., \& Faruq, M. . (2015). Tes dan Pengukuran dalam Olahraga. Andi Offset.

Kadek Yogi Parta, L. P. S. W. (2016). Pengaruh Model Dan Media Pembelajaran Terhadap Hasil Belajar Kemampuan Dasar Senam Lantai Pada Mahasiswa Jurusan Penjaskesrek Undiksha. JPI (Jurnal Pendidikan Indonesia). https://doi.org/10.23887/jpi-undiksha.v5i1.8932

Komarudin. (2016). Penilaian Hasil Belajar Pendidikan Jasmani dan Olahraga. PT Remaja Rosdakarya.

Lubis, H. Y., \& Heri, Z. (2018). Analisis Gerak Round Off Sebagai Rangkaian Gerak. Jurnal Prestasi, 2(4), 1-8.

Maulana, M. G., Suranto, S., \& Sulistianta, H. (2015). Hubungan Kekuatan Otot Lengan Dan Keseimbangan Dengan Kemampuan Meroda. Jurnal Penjaskesrek, 3(4).

Milham. (2014). Hubungan konsentrasi, kekuatan otot lengan dan keseimbangan tangan dengan ketepatan memanah. Jurnal Sport Pedagogy, 4(2), 19-24. 
Era Sakti Pertiwi, Didik Rilastiyo Budi, Rohman Hidayat, Neva Widanita \& Indra Jati Kusuma | Hubungan

Kekuatan Otot Lengan, Kelentukan dan Keseimbangan Dengan Kemampuan Gerak Senam Meroda

Mulyana, F. R. (2017). Pengaruh Gaya Mengajar dan Motivasi Belajar terhadap Hasil Belajar Stut Senam Lantai. JOURNAL SPORT AREA. https://doi.org/10.25299/sportarea.2017.vol2(1).454

Murtaqi, A., Mubin, D., \& Setiawan, W. (2018). Upaya Meningkatkan Hasil Belajar Gerak Meroda Dalam Senam Lantai Melalui Media Bola Gymnastic Pada Siswa Kelas VIII MTs Roudlotul Mutta'allimin. Jurnal Kejaora (Kesehatan Jasmani Dan Olahraga). https://doi.org/10.36526/kejaora.v3i2.214

Oksyalia, D., Suntoda, A., Mahendra, A., \& Hidayat, A. (2018). Upaya Meningkatkan Gerakan Meroda Menggunakan Pola Gerak Dominan dalam Pembelajaran Senam Lantai. TEGAR: Journal of Teaching Physical Education in Elementary School. https://doi.org/10.17509/tegar.v2i1.13777

Rindawan, \& Mulyajaya, M. S. (2016). Hubungan kekuatan otot lengan dan kekuatan otot perut dengan kemampuan melakukan sikap lilin pada senam lantai siswa kelas VIII SMPN Praya Tengah tahun pelajaran 2015/2016. Jurnal IImiah Mandala Education, 2(2), 230-236.

Setiawan, A., Yudiana, Y., Ugelta, S., Oktriani, S., Budi, D. R., \& Listiandi, A. D. (2020). Hasil Belajar Pendidikan Jasmani dan Olahraga Siswa Sekolah Dasar: Pengaruh Keterampilan Motorik (Tinggi) dan Model Pembelajaran (Kooperatif). TEGAR: Journal of Teaching Physical Education in Elementary School. https://doi.org/10.17509/tegar.v3i2.24513

Sugiyono, P. D. (2016). metode penelitian kuantitatif, kualitatif,dan R\&D. In Alfabeta, cV. Alfabeta.

Suherman, A. (2009). Revitalisasi Pengajaran dalam Pendidikan Jasmani. CV. Bintang Warli Artika.

Wahyu Heny Kartika Sari, Tatok Sugiarto, S. P. (2016). Pengembangan Pembelajaran Senam Lantai Rangkaian Sederhana Siswa Kelas VIII di SMP Negeri 2 ngoro Kabupaten Mojokerto. Jurnal Pendidikan Jasmani.

Widowati, A., \& Rasyono. (2013). Pengembangan Bahan Ajar Senam Lantai Untuk Pembelajaran Senam Dasar Pada Mahasiswa Fakultas Ilmu Keolahragaan Universitas Jambi. Journal of Chemical Information and Modeling.

Wuryantoro, K., \& Muktiani, N. R. (2011). Meningkatkan Keterampilan Senam Meroda Melalui Permainan Tali Pada Siswa Kelas Viiia Mts Ma 'Arif Nu. Jurnal Pendidikan Jasmani Indonesia.

Yulianto, R. (2018). Korelasi Power Otot Lengan, Kelentukan dan Kekuatan Otot Punggung dengan Kemampuan Handspring Senam Artistik. Jurnal IImiah Penjas (Penelitian, Pendidikan dan Pengajaran), 4(2), 17-34. http://202.91.10.29/index.php/JIP/article/view/695 